\title{
Diamond burr superficial keratectomy with mitomycin $C$ for corneal scarring and high corneal astigmatism after pterygium excision
}

This article was published in the following Dove Press journal:

Clinical Ophthalmology

23 May 2013

Number of times this article has been viewed

Engin Bilge Ozgurhan'

Necip Kara'

Aydin Yildirim²

Zeynep Alkin'

Ercument Bozkurt ${ }^{1}$

Ahmet Demirok ${ }^{1,3}$

'Beyoglu Eye Research and

Training Hospital, ${ }^{2}$ Department of

Ophthalmology, Sema Research and

Treatment Hospital, Fatih University,

${ }^{3}$ Department of Ophthalmology,

Istanbul Medeniyet University Medical

School, Istanbul, Turkey
Correspondence: Engin Bilge Ozgurhan Topkapi Merkez Evleri, 2. Etap B2 blok, D58, Zeytinburnu/lstanbul, Turkey Tel +905327009538

Email enginbilge@yahoo.com
Background: The purpose of this paper is to report the successful treatment of corneal scarring and high corneal astigmatism secondary to previous pterygium surgery with diamond burr superficial keratectomy using mitomycin $\mathrm{C}$.

Methods: Four patients with corneal scarring and high corneal astigmatism related to previous pterygium surgery underwent diamond burr superficial keratectomy with application of mitomycin C. Anterior segment photography and corneal topographic analysis were obtained preoperatively and postoperatively in all patients.

Results: Six months after surgery, corneal astigmatism and corneal aberrations were reduced in all patients. A clear cornea was achieved in all cases. No complications were noted during the follow-up period.

Conclusion: Diamond burr superficial keratectomy with application of mitomycin $\mathrm{C}$ is a potentially effective and simple procedure for treating patients with corneal scarring and high corneal astigmatism secondary to previous pterygium surgery.

Keywords: diamond burr superficial keratectomy, astigmatism, pterygium surgery

\section{Introduction}

Pterygium is an ocular surface disorder seen frequently in ophthalmology practice. It has a considerable negative effect on corneal refractive status, which has been previously reported in various studies on refraction, keratometry, and corneal topography. ${ }^{1}$ Pterygium may cause visual impairment by local flattening of the cornea and inducing with-the-rule astigmatism. ${ }^{2,3}$

Previous studies have demonstrated that the topographical changes in the cornea and visual impairment induced by pterygium can be reversed following removal. ${ }^{2,3}$ However, sometimes a pterygium surgery that was not performed effectively causes a remnant pterygium tissue on the cornea, which leads to corneal scarring, high astigmatism, and reduced visual function. Few studies have been reported in the literature related to corneal scarring and high corneal astigmatism secondary to pterygium surgery and their treatment.

Herein we report four cases with corneal scarring and high corneal astigmatism caused by pterygium remnant after pterygium surgery and treatment of these conditions with diamond burr superficial keratectomy and application of mitomycin C.

\section{Materials and methods}

Retrospective chart analysis was performed for four patients who were referred to our hospital for treatment of corneal scarring and high corneal astigmatism secondary 
Table I Visual and refractive changes in patients before and six months after surgery

\begin{tabular}{|c|c|c|c|c|c|c|c|c|c|}
\hline \multirow[t]{2}{*}{ Case } & \multirow[t]{2}{*}{ Age/gender/eye } & \multicolumn{2}{|l|}{ UCVA } & \multicolumn{2}{|c|}{ BSCVA } & \multicolumn{2}{|c|}{ KI-K2/cylinder } & \multicolumn{2}{|l|}{ Refraction } \\
\hline & & Preop & Postop & Preop & Postop & Preop & Postop & Preop & Postop \\
\hline \multirow[t]{2}{*}{ I } & $5 I / M / R$ & 0.1 & 0.7 & 0.3 & 0.9 & $38.3-43.5 /$ & $40.2-42.0 /$ & $+6.50-8.0 \times 154$ & $+1.0-1.50 \times 25$ \\
\hline & & & & & & -5.28 & -1.79 & & \\
\hline \multirow[t]{2}{*}{2} & $55 / F / R$ & 0.3 & 0.9 & 0.5 & 1.0 & $42.2-46.5 /$ & $44.4-45.3 /$ & $+4.50-6.0 \times 15$ & $+0.50-1.25 \times 100$ \\
\hline & & & & & & -4.35 & -0.92 & & \\
\hline \multirow[t]{2}{*}{3} & $56 / \mathrm{M} / \mathrm{L}$ & 0.2 & 0.8 & 0.5 & 1.0 & $38.2-46.7 /$ & $43.1-44.2 /$ & $+6.0-7.0 \times 30$ & $+1.0-1.25 \times 140$ \\
\hline & & & & & & -8.57 & -1.11 & & \\
\hline \multirow[t]{2}{*}{4} & $62 / F / L$ & 0.2 & 0.7 & 0.4 & 0.9 & $36.5-46.9 /$ & $42.3-44.2 /$ & $+4.50-7.0 \times 10$ & $+0.50-1.75 \times 30$ \\
\hline & & & & & & -10.4 & -1.84 & & \\
\hline
\end{tabular}

Abbreviations: UCVA, uncorrected visual acuity; BSCVA, best spectacle-corrected visual acuity; K, keratometry; M, male; F, female; R, right; L, left; preop, preoperatively; postop, postoperatively.

to residual pterygium tissue after pterygium surgery. Phototherapeutic keratectomy was offered to all the patients by previous clinics. The advantages and disadvantages of our treatment were fully explained, and informed consent was obtained from each patient.

After a complete history was taken, all patients underwent a comprehensive ocular examination. Anterior segment imaging was achieved by a high definition external camera and a corneal topographic analysis was performed using a Scheimpflug camera (Sirius, Costruzioni Strementi Oftalmici, Italy) with a Placido disc topographer at baseline and at postoperative follow-up.

\section{Surgical procedure}

All surgeries were performed with topical anesthesia by the same surgeon (EBO) at the Beyoglu Eye Research and Training Hospital. The corneal epithelium around the pterygium remnant was removed down to Bowman's layer and residual pterygium tissue was scraped by a crescent knife. Diamond burr polishing was then performed to smooth the entire corneal surface. A handheld batterydriven ophthalmic burr with a $3.3 \mathrm{~mm}$ diameter diamonddusted sphere was used to polish the corneal surface for approximately $10-15$ seconds. To avoid haze, mitomycin C

A

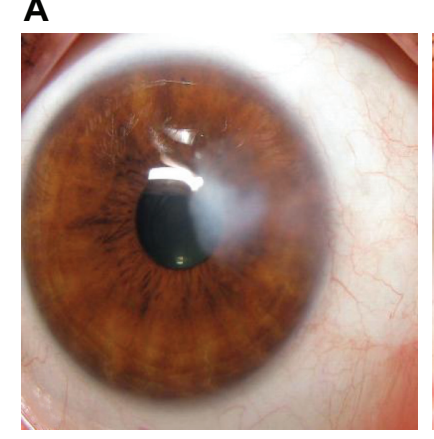

Figure I Appearance of case 2 (A) before and (B) six months after surgery.
$(0.2 \mathrm{mg} / \mathrm{mL})$ was applied for one minute with a Weck-Cel ${ }^{\circledR}$ sponge (Beaver-Visitec International, Waltham, MA, USA) and the eye was thoroughly irrigated with balanced salt solution. A soft bandage contact lens was placed on the eye at the end of the procedure. Postoperatively, the patient was instructed to instill a topical steroid, a topical antibiotic, and artificial tears, each four times daily, for one month after surgery. The contact lens was removed five days after the procedure. The patients were followed for at least six months.

\section{Results}

Demographic characteristics and clinical outcomes for the patients are shown in Table 1. On refractive examination, four patients had low uncorrected and best spectaclecorrected visual acuity, which had improved by six months after surgery (Table 1). In all four patients, slit-lamp examination revealed corneal scarring and residual tissues in the area of previous pterygium tissue at baseline (Figures 1 and 2). At six months postoperatively, the corneal lesions were decreased or had disappeared. Corneal topographic evaluation revealed high corneal astigmatism and elevated high corneal aberrations (Figures 3 and 4). After surgery, the corneal astigmatism and corneal aberrations were reduced (Table 2).
A

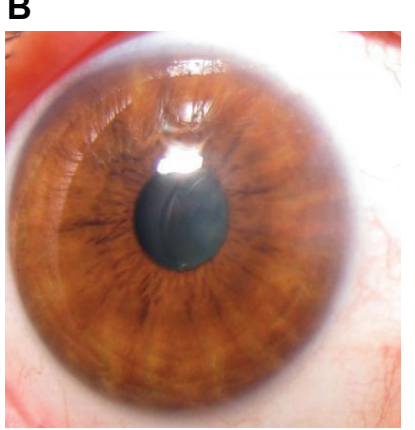

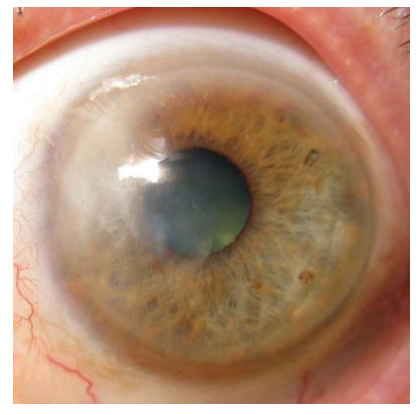

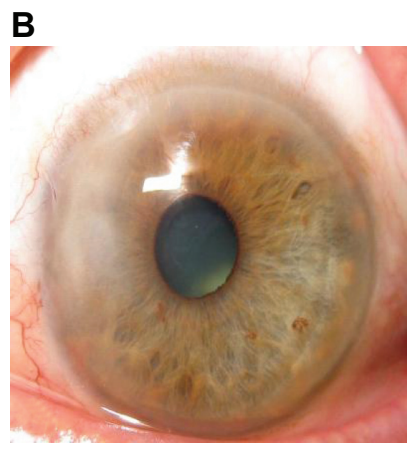

Figure 2 Appearance of case 3 (A) before and (B) six months after surgery. 

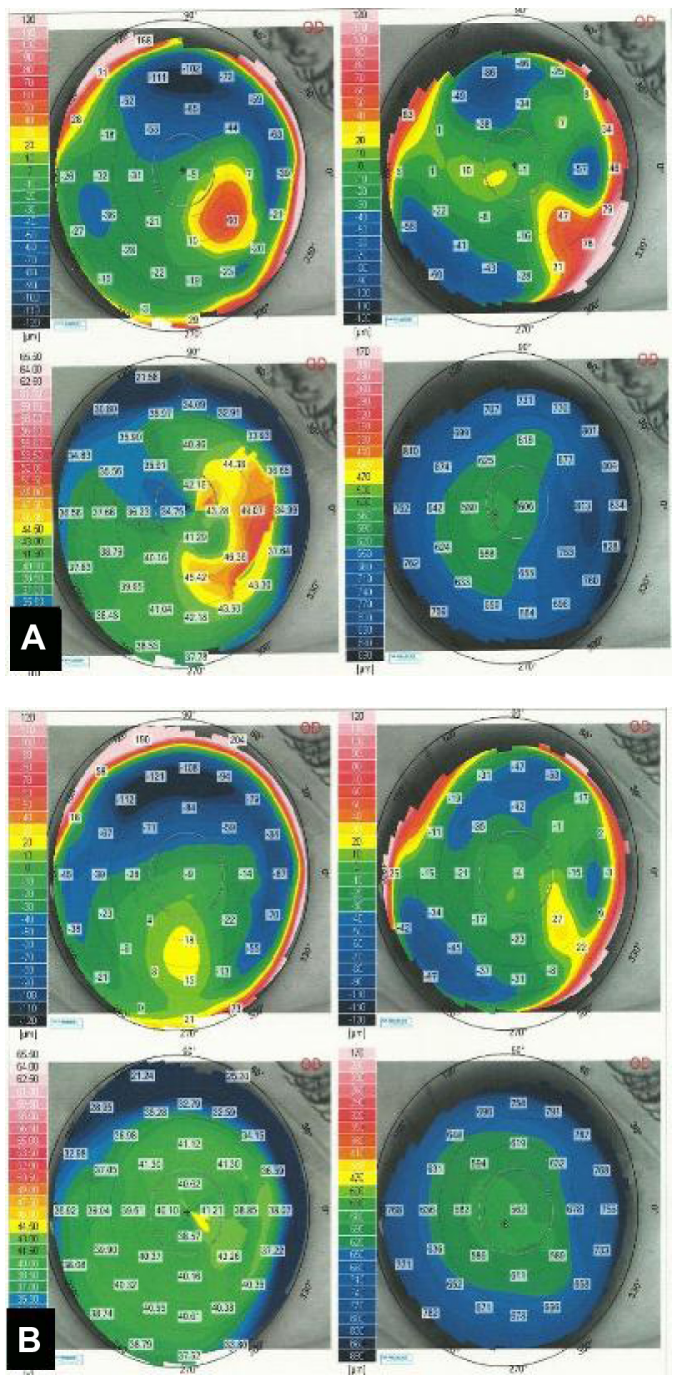

Figure 3 Corneal topography of case I (A) before and (B) six months after surgery.

\section{Discussion}

Pterygium can induce a significant amount of astigmatism in proportion to its size. It generally causes with-the-rule corneal astigmatism that is hemimeridional on the side of the pterygium, which results in a localized flattening of the cornea central to the leading apex. Although many previous studies ${ }^{1,2}$ have established that pterygium surgery decreases pterygium-induced astigmatism, corneal distortion may not
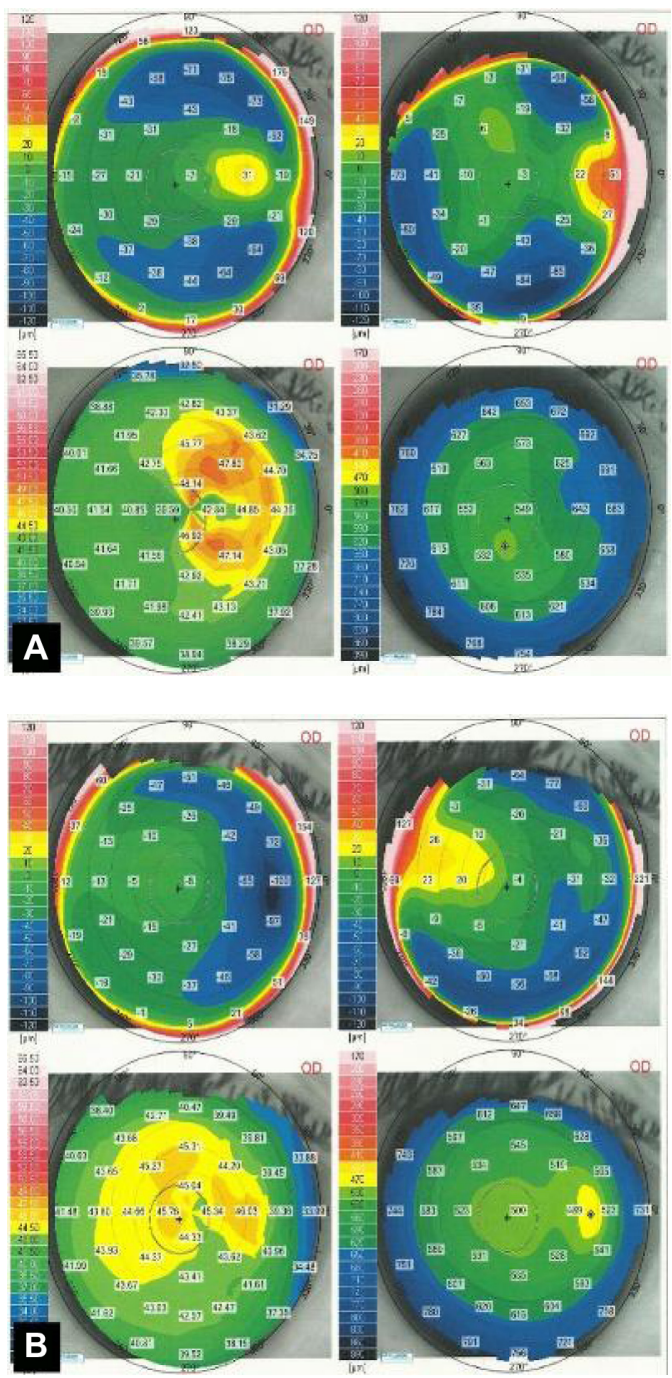

Figure 4 Corneal topography of case 2 (A) before and (B) six months after surgery.

be completely normalized in eyes with advanced pterygium, and irregular topographical changes may persist especially if the pterygium reached the paracentral zone of the cornea. ${ }^{4}$ On the other hand, a pterygium remnant after pterygium surgery may cause visual impairment secondary to corneal scarring or induced astigmatism.

There are several modalities available to treat eyes with anterior corneal scars, which may be post-traumatic,

Table 2 Higher order corneal aberrations in patients before and six months after surgery

\begin{tabular}{|c|c|c|c|c|c|c|c|c|c|c|}
\hline \multirow[t]{2}{*}{ Case } & \multicolumn{2}{|c|}{$\begin{array}{l}\text { Higher order } \\
\text { RMS }(\mu \mathrm{m})\end{array}$} & \multicolumn{2}{|c|}{$\begin{array}{l}\text { Astigmatism } \\
\text { RMS }(\mu \mathrm{m})\end{array}$} & \multicolumn{2}{|c|}{ Coma $(\mu \mathrm{m})$} & \multicolumn{2}{|c|}{ Trifoil $(\mu \mathrm{m})$} & \multicolumn{2}{|c|}{$\begin{array}{l}\text { Spherical } \\
\text { aberration }(\mu \mathrm{m})\end{array}$} \\
\hline & Preop & Postop & Preop & Postop & Preop & Postop & Preop & Postop & Preop & Postop \\
\hline I & 2.33 & 1.63 & 5.50 & 1.95 & 1.67 & 0.07 & 0.44 & 1.14 & 0.87 & 0.12 \\
\hline 2 & 2.28 & 0.77 & 3.50 & 0.70 & 0.44 & 0.38 & 1.80 & 0.50 & 0.52 & 0.29 \\
\hline 3 & 4.43 & I.II & 5.39 & 0.91 & 0.95 & 0.31 & 1.15 & 0.66 & 6.15 & 1.36 \\
\hline 4 & 6.55 & $\mathrm{I} .42$ & 6.16 & 1.07 & 0.51 & 0.38 & 4.56 & 0.87 & 1.66 & 0.23 \\
\hline
\end{tabular}

Abbreviations: RMS, root mean square; preop, preoperatively; postop, postoperatively. 
post-infectious, or post-pterygium excision. ${ }^{5,6}$ Excimer laser phototherapeutic keratectomy is the most commonly recommended technique for superficial corneal opacities localized over one-third of the superficial stroma. Phototherapeutic keratectomy is also used to smooth irregular corneal surfaces caused by corneal disease, thereby improving the optical properties of the cornea and resulting in improved visual function. ${ }^{7}$ Scars following pterygium surgery can be treated either as a primary scar or as a topography-guided treatment, with correction of irregular astigmatism. .,6 $^{5}$

Herein we describe a simple, cheap, and effective procedure to treat anterior corneal scars and high corneal astigmatism related to previous pterygium surgery. Using this procedure, we achieved a decrease in corneal astigmatism and corneal aberrations, which resulted in visual improvement. This procedure has some advantages over phototherapeutic keratectomy. First, this technique does not induce a tissue reaction as in the case of excimer laser ablation. Second, the technique is cheaper than phototherapeutic keratectomy. Although requiring only a crescent knife and a handheld battery-driven ophthalmic burr, excimer laser phototherapeutic keratectomy requires more comprehensive equipment. Third, one of the difficulties with phototherapeutic keratectomy is preoperative estimation of the depth of pathology and determination of the amount of tissue to be removed during the procedure. However, this technique described here allows controlled scraping of the lesion.

This study has some limitations, including a small sample size and a short follow-up period. Larger studies with longterm follow-up are needed to validate our findings. Moreover, we did not address the safety of mitomycin C. Several studies have reported that use of topical mitomycin $\mathrm{C}$ during pterygium surgery had a deleterious effect on the corneal endothelium postoperatively. ${ }^{8-10}$

\section{Conclusion}

In conclusion, diamond burr superficial keratectomy with application of mitomycin $\mathrm{C}$ is a simple and effective procedure for treatment of corneal scarring secondary to previous pterygium surgery. This technique might be considered by surgeons in cases with anterior corneal scars related to pterygium surgery. However, larger prospective studies are required to confirm the effectiveness of the procedure.

\section{Disclosure}

The authors have no proprietary interests or conflicts of interest related to this work.

\section{References}

1. Yagmur M, Ozcan AA, Sari S, Ersöz TR. Visual acuity and corneal topographic changes related with pterygium surgery. J Refract Surg. 2005;21(2):166-170.

2. Cinal A, Yasar T, Demirok A, Topuz H. The effect of pterygium surgery on corneal topography. Ophthalmic Surg Lasers. 2001;32(1):35-40.

3. Pesudovs K, Figueiredo FC. Corneal first surface wavefront aberrations before and after pterygium surgery. J Refract Surg. 2006;22(9):921-925.

4. Tomidokoro A, Oshika T, Amano S, Eguchi K, Eguchi S. Quantitative analysis of regular and irregular astigmatism induced by pterygium. Cornea. 1999;18(4):412-415.

5. Maloney RK, Thompson V, Ghiselli G, Durrie D, Waring GO 3rd, O'Connell M. A prospective multicenter trial of excimer laser phototherapeutic keratectomy for corneal vision loss: the Summit Phototherapeutic Keratectomy Study Group. Am J Ophthalmol. 1996; 122(2):149-160.

6. Zaidman GW, Hong A. Visual and refractive results of combined PTK/ PRK in patients with corneal surface disease and refractive errors. J Cataract Refract Surg. 2006;32(6):958-961.

7. Dogru M, Katakami C, Yamanaka A. Refractive changes after excimer laser phototherapeutic keratectomy. J Cataract Refract Surg. 2001; 27(5):686-692.

8. Bahar I, Kaiserman I, Lange AP, et al. The effect of mitomycin C on corneal endothelium in pterygium surgery. Am J Ophthalmol. 2009; 147(3):447-452.

9. Kheirkhah A, Izadi A, Kiarudi MY, Nazari R, Hashemian H, Behrouz MJ. Effects of mitomycin $\mathrm{C}$ on corneal endothelial cell counts in pterygium surgery: role of application location. Am J Ophthalmol. 2011;151(3): 488-493.

10. Avisar R, Apel I, Avisar I, Weinberger D. Endothelial cell loss during pterygium surgery: importance of timing of mitomycin $\mathrm{C}$ application. Cornea. 2009;28(8):879-881.
Clinical Ophthalmology

\section{Publish your work in this journal}

Clinical Ophthalmology is an international, peer-reviewed journal covering all subspecialties within ophthalmology. Key topics include: Optometry; Visual science; Pharmacology and drug therapy in eye diseases; Basic Sciences; Primary and Secondary eye care; Patient Safety and Quality of Care Improvements. This journal is indexed on Submit your manuscript here: http://www.dovepress.com/clinical-ophthalmology-journal

\section{Dovepress}

PubMed Central and CAS, and is the official journal of The Society of Clinical Ophthalmology (SCO). The manuscript management system is completely online and includes a very quick and fair peer-review system, which is all easy to use. Visit http://www.dovepress.com/ testimonials.php to read real quotes from published authors. 